\title{
IDENTIFIKASI KELAYAKAN LOKASI LAHAN BUDI DAYA LAUT DI PERAIRAN TELUK KUPANG, NUSA TENGGARA TIMUR
}

\author{
Utojo, Abdul Mansyur, Tarunamulia, Brata Pantjara, dan Hasnawi
}

\begin{abstract}
ABSTRAK
Nusa Tenggara Timur memiliki sumber daya lahan perikanan pesisir yang cukup potensial untuk pengembangan budi daya laut, namun demikian belum diperoleh data rinci kelayakannya. Penelitian ini bertujuan untuk menentukan kelayakan lokasi bagi pengembangan budi daya laut di perairan Teluk Kupang, Kabupaten Kupang, Nusa Tenggara Timur dan penelitiannya dilaksanakan dengan menggunakan metode survai. Pengumpulan data sekunder meliputi data iklim, data produksi perikanan, peta rupa bumi indonesia kawasan Kupang skala 1:25.000, citra digital landsat-7 ETM, dan peta navigasi (batimetri) skala 1:200.000 yang dilakukan sebelum pelaksanaan survai. Data primer diperoleh melalui pengukuran langsung di lapangan yang meliputi topografi pantai dan dasar perairan, keterlindungan, oseanografi, dan biologi. Seluruh lokasi pengambilan contoh ditentukan posisinya dengan GPS dan data yang diperoleh dianalisis dengan menggunakan SIG. Dari hasil penelitian ini telah diidentifikasi sumber daya lahan perikanan pesisir yang potensial dikembangkan untuk budi daya laut yaitu seluas $2.849,1$ hektar. Berdasarkan hasil survai dan evaluasi kelayakan sumber daya lahan perikanan pesisir di perairan Teluk Kupang dinilai layak untuk pengembangan budi daya laut. Lokasi lahan budi daya ikan dalam keramba jaring apung terdapat di sekitar Pulau Burung (439,5 hektar), Pulau Semau dan Pulau Kambing $(483,1$ hektar). Lokasi lahan budi daya rumput laut terdapat di sekitar Pulau Burung (592,3 hektar), Pulau Semau dan Pulau Kambing (1.038 hektar). Lokasi lahan budi daya kerang mutiara terdapat di sebelah timur Pulau Semau (296,2 hektar), masing-masing dituangkan dalam peta prospektif skala 1:50.000.
\end{abstract}

ABSTRACT: Identification of area suitability for mariculture in Kupang Bay, Kupang Regency, East Nusa Tenggara. By: Utojo, A. Mansyur, Tarunamulia, Brata Pantjara, and Hasnawi

East Nusa Tenggara has coastal resources which are potential to develop mariculture, but the scientific support was unavailable. This study was conducted enough survey method to find out location which was suitable to develop mariculture in Kupang Bay, Kupang Regency, East Nusa Tenggara. Secondary data such as wheather data, coastal fisheries production data, Indonesia earth surface map of Kupang area scale of 1:25,000, landsat-7 ETM digital image product, and navigation map scale 1:200,000 were conducted before the study. The primary data were collected from each study area and interpreted as mariculture requirements for several domesticated species i.e. fish, seaweed, and shellfish. Tematic map of area suitability as the main expected output of the study was made through spatial analysis and G/S as suggested by reference. The potential areas which are suitable for mariculture development are 2,849.1 hectares, namely either for fish culture in floating net cage (922.6 hectares), seaweed (1,630.3 hectares), or bivalves (296.2 hectares) distributed in the sea waters of Burung, Semau, and Kambing Island.

KEYWORDS: natural resources, coastal, site selection, geographycal information system

\section{PENDAHULUAN}

Usaha perikanan budi daya laut merupakan satu di antara kegiatan pemanfaatan kawasan pesisir yang mampu memberikan kontribusi cukup besar terhadap pendapatan daerah, peningkatan kesejahteraan masyarakat pesisir melalui penyediaan lapangan kerja baru, dan perolehan devisa negara yang potensial. Perairan di Kawasan Timur Indonesia (KTI) mempunyai potensi yang sangat besar untuk pengembangan budi daya laut. Satu kawasan di antaranya adalah Nusa Tenggara Timur yang memiliki potensi sumber daya lahan budi daya laut yang masih lestari dan belum dimanfaatkan secara optimal. Luas sebaran potensi lahan perikanan pesisir untuk penerapan budi daya laut belum seluruhnya dievaluasi melalui hasil survai seperti identifikasi, karakterisasi, dan pemetaan kelayakannya. Pentingnya riset pemetaan lahan budi daya laut adalah untuk mengevaluasi kembali potensi lahan perikanan pesisir yang telah mengalami

Peneliti pada Balai Riset Perikanan Budidaya Air Payau, Maros 
perubahan topografi pantai dan dasar perairan akibat proses alam dan kegiatan manusia serta mendapatkan lokasi dan luas lahan budi daya laut terkini. Aplikasi riset pemetaan diharapkan dapat dijadikan acuan dalam pengembangan kegiatan model budi daya perikanan pesisir yang ramah lingkungan berorientasi peningkatan produksi hasil budi daya laut melalui tingkat paket teknologi yang akan diterapkan dan dapat menghindarkan konflik kepentingan baik dalam sektor kelautan/perikanan maupun dengan sektor lain.

Provinsi Nusa Tenggara Timur berada di sebelah selatan wilayah Indonesia, merupakan daerah kepulauan yang terdiri atas Pulau Flores, Sumba, Timor, dan Alor serta beberapa pulau kecil lainnya yang berjumlah 566 pulau di mana 42 pulau dihuni oleh manusia. Kabupaten Kupang merupakan satu di antara 13 kabupaten di Provinsi Nusa Tenggara Timur yang diprioritaskan untuk pengembangan perikanan pesisir dengan pusat pertumbuhannya Kota Kupang. Teluk Kupang di dalamnya terdiri atas beberapa pulau antara lain Pulau Burung, Pulau Tikus, Pulau Kera, dan perairan pantai Pulau Semau dan Pulau Kambing serta Pulau Rote yang saat ini terdapat kegiatan budi daya rumput laut dan kerang mutiara dengan metode tali gantung yang sangat potensial sebagai sentra pengembangan budi daya laut. Kabupaten Kupang pada posisi $121^{\circ} 30^{\prime}$ sampai $124^{\circ} 11^{\prime}$ Bujur Timur dan 9'19' sampai $10^{\circ} 57^{\prime}$ 'Lintang Selatan serta memiliki luas wilayah $7.178,28 \mathrm{~km}^{2}$. Permukaan tanah mulai dari dataran rendah, berbukit sampai bergununggunung dengan tingkat kemiringan rata-rata mencapai $45^{\circ}$, beriklim kering di mana musim hujan (Desember sampai April) lebih pendek daripada musim kemarau (April sampai November) (Anonim, 2000).

Untuk kegiatan budi daya laut yang berhasil guna dan berdaya guna, maka penentuan lokasi sesuai dengan kondisi perairan, jenis komoditi yang tepat, metode budi daya yang unggul, dan dekat dengan pusat konsumen perlu menjadi perhatian. Kendala dalam pengembangan budi daya laut di perairan Teluk Kupang di antaranya adalah masih terbatasnya data rinci dan informasi mengenai ketepatan kelayakan potensi sumber daya lahan yang dapat dijadikan acuan dalam mengelola sumber daya tersebut secara optimal serta belum jelasnya legalitas dan kepastian dalam pemanfaatan kawasan perikanan pesisir untuk budi daya laut. Karena itu, identifikasi, karakterisasi, dan pemetaan sumber daya lahan perikanan pesisir untuk budi daya laut sangat dibutuhkan dalam menentukan skala prioritas teknologi budi daya yang akan diterapkan dan sasaran komoditas yang akan dikembangkan di wilayah tersebut. Penelitian ini bertujuan untuk menentukan lokasi dan luas sumber daya lahan perikanan pesisir yang layak bagi pengembangan budi daya laut (ikan, rumput laut, dan kekerangan) di perairan Teluk Kupang.

\section{BAHAN DAN METODE}

Kegiatan riset pemetaan kelayakan lokasi lahan budi daya laut dilaksanakan pada bulan September dan November 2002 di perairan Teluk Kupang, Kabupaten Kupang, Nusa Tenggara Timur dengan pemilihan lokasi survai ditentukan berdasarkan pada program Badan Perencanaan Pembangunan Daerah (Bappeda) dan Dinas Kelautan dan Perikanan (Dislutkan) Provinsi Nusa Tenggara Timur dan Kabupaten Kupang, mengenai pengembangan wilayah perikanan pesisir untuk penerapan budi daya laut.

Penelitian ini menggunakan metode survai yang dirancang berdasarkan Sistem Informasi Geografis (SIG). Penentuan stasiun pengamatan sebanyak 12 titik dilakukan dengan simple random sampling (Clark \& Hosking, 1986) dan penyebarannya dapat mewakili lokasi penelitian. Setiap titik stasiun pengamatan ditentukan posisi atau titik koordinatnya dengan alat GPS (Global Positioning System). Sebaran titik stasiun pengamatan di lokasi penelitian dapat dilihat pada Gambar 1.

Diagram alur analisis spasial pada pemetaan kelayakan lokasi lahan budi daya laut dengan menggunakan teknologi SIG disajikan pada Gambar 2.

Data yang diperlukan dalam kegiatan riset pemetaan ini antara lain:

1). Data sekunder berupa peta dasar digital kawasan Teluk Kupang yang dibuat dan bersumber pada peta rupa bumi Indonesia kawasan Kabupaten Kupang skala 1:25.000, tahun 1991 yang diperoleh dari Badan Koordinasi Survei dan Pemetaan Nasional (Bakosurtanal), peta navigasi (batimetri) yang menggambarkan kedalaman laut daerah pantai Kupang skala 1:200.000, nomor 321, tahun 1991 yang diperoleh dari Dinas Hidro-Oseanografi Angkatan Laut (Dishidros-AL), dan peta citra landsat-7 ETM kawasan Teluk Kupang, tahun 2002 yang diperoleh dari Lembaga Penerbangan dan Antariksa Nasional (LAPAN) yang menggambarkan kondisi tata guna lahan terkini.

Proses analisis awal dari pembuatan peta dasar digital kawasan Teluk Kupang, dimulai dari scan atau proyeksi peta rupa bumi ke dalam peta dasar. Informasi yang diambil dari peta rupa bumi dan batimetri meliputi garis pantai, sungai, garis batas wilayah, jaringan transportasi (jalan), mangrove, penggunaan lahan, sebaran penduduk (pemukiman), letak dan nama lokasi, garis kontur 


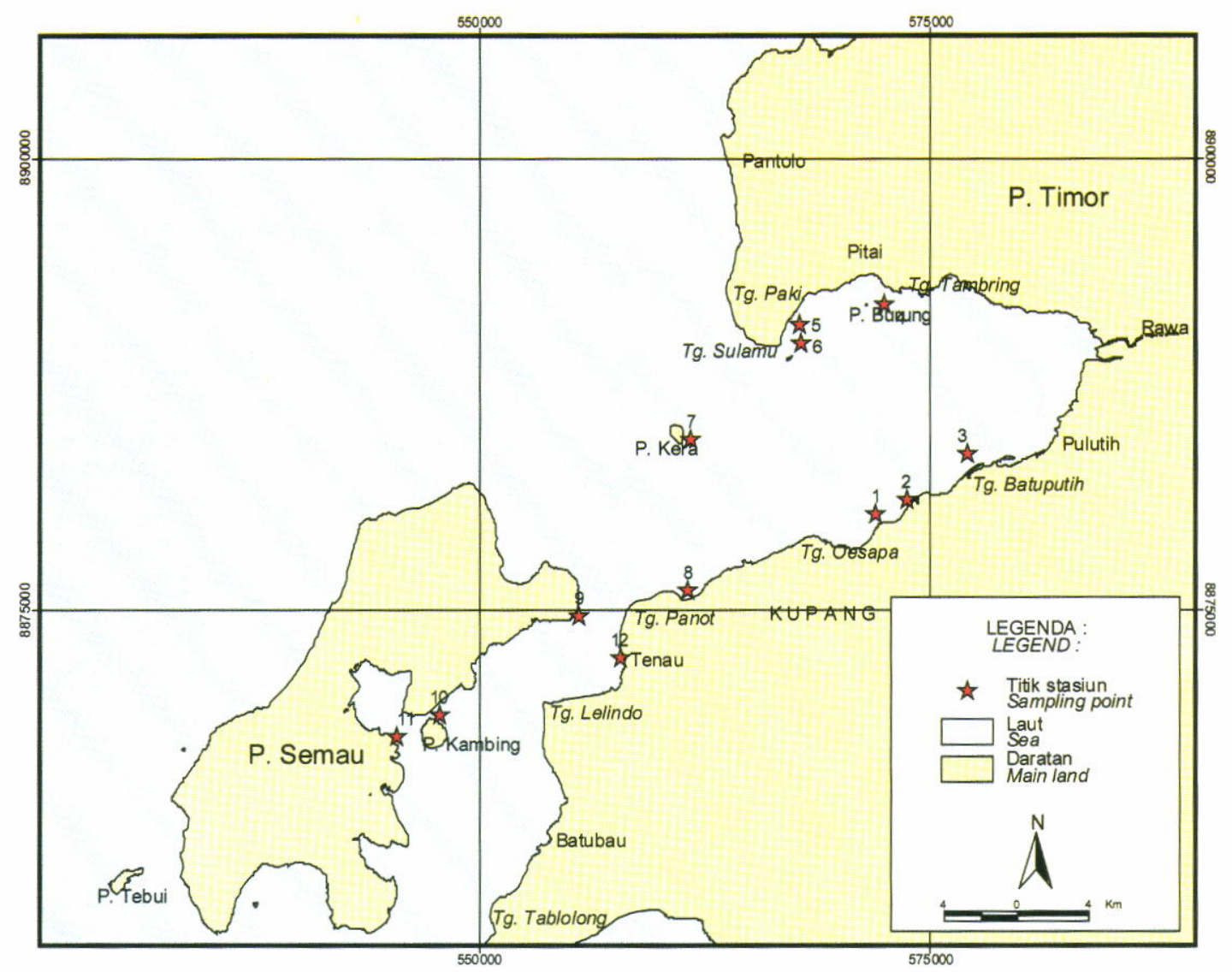

Gambar 1. Peta sebaran stasiun pengamatan kelayakan lahan budi daya laut di perairan Teluk Kupang, Nusa Tenggara Timur

Figure 1. Map of sampling station distribution of mariculture location suitability in Kupang Bay, East Nusa Tenggara

atau ketinggian daratan, dan kedalaman laut. Kemudian dilakukan regristrasimemindahkan titik koordinat peta rupa bumi ke dalam peta dasar, selanjutnya memindahkan peta citra landsat-7 ETM ke dalam peta dasar dengan program er-mapper untuk mendapatkan kondisi tataguna lahan terkini. Setelah itu dilakukan digitasi dan topologi yaitu mendigitasi dan mengidentifikasi peta dasar dengan informasi yang telah diambil dari peta rupa bumi dan citra. Kemudian diperoleh hasil peta dasar digital kawasan Teluk Kupang yang menjadi objek proses analisis spasial selanjutnya. Peng-edit-an atau verifikasi dilakukan mulai dari scan atau proyeksi peta rupa bumi ke dalam peta dasar pada pembuatan peta dasar digital sampai ke gambaran umum peta kelayakan lokasi lahan budi daya laut yang siap dicetak. Pentingnya peng-edit-an atau verifikasi adalah untuk mengurangi distorsi atau perubahan penggambaran dalam peta yang berakibat terjadinya perubahan letak, jarak, arah antar lokasi, dan luas keseluruhan wilayah teluk serta luas kelayakan lokasi lahan budi daya laut.
2). Data primer berupa data fisik oseanografi yang diperoleh dari lokasi penelitian meliputi topografi pantai, keterlindungan, fisik: ombak, arus, pasang surut, kedalaman, dan substrat dasar; mutu air: $\mathrm{pH}$, suhu, salinitas, kekeruhan, kecerahan, pencemar (logam berat: $\mathrm{Pb}, \mathrm{Cd}, \mathrm{Zn}$, dan $\mathrm{Cu}$ ), DO, $\mathrm{NO}_{3}-\mathrm{N}, \mathrm{NO}_{2}-\mathrm{N}, \mathrm{NH}_{3}-\mathrm{N}, \mathrm{PO}_{4}-\mathrm{P}$; dan biologi (plankton). Peubah tersebut yang akan digunakan sebagai dasar skala penilaian dan bobot pada kelayakan lahan untuk budi daya laut (ikan, rumput laut, dan kekerangan) dengan mengacu pada persyaratan yang disarankan oleh Ahmad et al. (1991); Mubarak et al. (1990); dan Atjo (1992). Cara mendapatkan skala penilaian dan bobot terhadap kelayakan lahan untuk budi daya laut mengacu pada persyaratan yang disarankan oleh Anonim (1999) terlihat pada Lampiran 1, 2, dan 3.

Cara mendapatkan skala penilaian dan bobot tersebut adalah sebagai berikut: pembobotan pada setiap faktor pembatas/peubah ditentukan berdasarkan pada dominannya peubah tersebut terhadap suatu peruntukan kelayakan lahan budi daya 


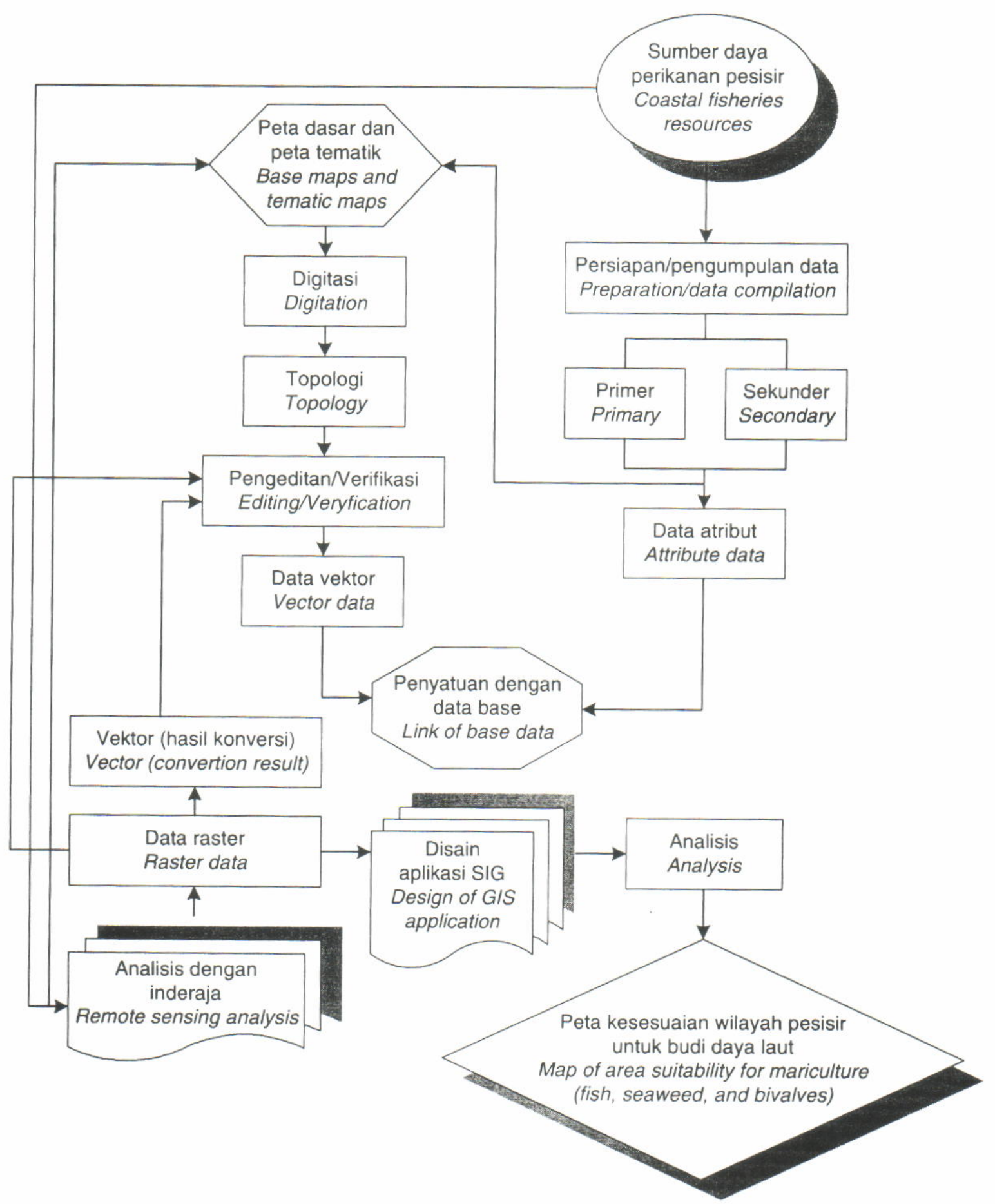

Gambar 2. Skema analisis terintegrasi SIG dan inderaja pada pembuatan peta kelayakan wilayah pesisir untuk budi daya laut (ikan, rumput laut, dan kekerangan)

Figure 2. Schema of GIS integration analysis and remote sensing at the coastal area suitability mapping for mariculture (fish, seaweed, and bivalves)

laut (ikan, rumput laut, dan kekerangan). Kemudian diurutkan faktor-faktor pembatas tersebut dimulai dari yang paling berpengaruh terhadap suatu peruntukan. Bobot terbesar ditentukan 1,00 dan terkecil 0,00. Semua bobot berjumlah 1,00. Dengan demikian, karena jumlah faktor pembatas dalam matriks cukup banyak, maka umumnya setiap faktor tersebut mempunyai bobot berupa pecahan antara 0,00 sampai 1,00. Untuk setiap faktor pembatas dalam kolom matriks dibuat skala penilaian dengan angka 
dari mulai 1 (kurang layak), 2 (cukup layak), 3 (layak), dan 4 (sangat layak). Kemudian dihitung perkalian bobot dengan skala penilaian untuk menentukan nilai akhir (skor) dari faktor-faktor tersebut. Kemudian dihitung skor total semua faktor pembatas dari setiap kolom skala penilaian dari mulai 1,00 (kurang layak) sampai 4,00 (sangat layak). Kisaran persentase skala penilaian pada setiap kolom yaitu nilai $4,00(100 \%)=$ S1 (sangat layak); 3,00 (75\%-99\%) = S2 (layak); $2,00(50 \%-74 \%)=$ S3 (cukup layak); $1,00(<50 \%)=$ $\mathrm{N}$ (kurang layak).

Menurut Hidayat et al. (1995), pengertian skala penilaian pada setiap kolom adalah sebagai berikut: S1 (sangat layak), apabila lahan tidak mempunyai pembatas yang berarti untuk mempertahankan tingkat pengelolaan yang harus diterapkan; S2 (layak), apabila lahan mempunyai pembatas agak berarti untuk mempertahankan tingkat pengelolaan yang harus diterapkan; S3 (cukup layak), apabila lahan mempunyai pembatas yang berarti untuk mempertahankan tingkat pengelolaan yang harus diterapkan; $\mathbf{N}$ (kurang layak), apabila lahan mempunyai faktor pembatas cukup berat, sehingga mencegah kemungkinan penggunaannya.

Menganalisis secara spasial dengan SIG (Purwadhi et al., 1997), bertujuan untuk menentukan kesesuaian lokasi lahan budi daya laut dengan komoditas ikan, rumput laut, dan kekerangan. Pada proses analisis tersebut dalam program arcview 3.3, data primer hasil dari setiap peubah fisik oseanografi disatukan dalam peta dasar digital dengan menginterpolasi pada setiap titik koordinat pengamatan menjadi area (polygon) menggunakan metode "Nearest Neighbor" (Morain, 1999). Dari hasil interpolasi setiap peubah fisik oseanografis yang diperoleh, kemudian disusun dalam bentuk peta tematik dengan layer-layer yang terpisah, melalui pertimbangan tingkat pembobotan dan skala penilaian, kemudian di-overlay (tumpang susun) untuk mendapatkan nilai kesesuaian lahan dan peta terkini yang menggambarkan prospek peruntukan sumber daya lahan perikanan pesisir di Teluk Kupang, bagi pengembangan budi daya ikan dalam keramba jaring apung, rumput laut, dan kekerangan.

\section{HASIL DAN BAHASAN}

\section{Kondisi Umum Kawasan Teluk Kupang}

Dalam peningkatan produksi perikanan budi daya di Teluk Kupang di masa datang, diharapkan mampu memberikan kontribusi yang sangat besar terhadap pendapatan masyarakat pesisir dan pemerintah daerahnya. Kondisi saat ini di Teluk Kupang 1) tersedia zonasi peruntukan lokasi dan luas lahan terkini untuk pengembangan budi daya ikan dalam keramba jaring apung, budi daya rumput laut, dan budi daya kerang mutiara yang ramah lingkungan dan berlanjut, 2) terdapat upaya pemanfaatan lahan di perairan teluk untuk kegiatan usaha budi daya rumput laut dan kerang mutiara serta penampungan ikan kerapu, kakap, dan beronang yang dilakukan oleh masyarakat dan swasta.

Keberadaan fasilitas di Kota Kupang yang mendukung pengembangan usaha budi daya laut meliputi fasilitas jalan utama di sepanjang teluk, cool storage, tempat pengolahan ikan, tempat pendaratan ikan di Desa Namosain, dan pelabuhan besar perikanan di Desa Tenau. Sarana dan prasarana ini sangat memudahkan dalam transportasi benih dan sarana produksi budi daya serta pemasaran produksi perikanan budi daya laut ke seluruh wilayah kabupaten di Provinsi Nusa Tenggara Timur, antar pulau, dan untuk ekspor. Adanya faktor penunjang dan mekanisme pengelolaannya saat ini masih bersumber dari hasil tangkapan ikan dari laut.

Jumlah penduduk di Kabupaten Kupang sebanyak 221.095 jiwa yang tersebar di desa, kota, dan di sekitar teluk. Di kabupaten ini terdapat dua buah sungai yaitu Sungai Oesao dan Manikin dengan panjang sungai masing-masing $30 \mathrm{~km}$ dan bermuara ke teluk. Namun demikian selalu mengalami kering terutama pada musim kemarau. Saat ini hasil buangan dari kegiatan masyarakat di bagian hulu yang bermuara ke teluk dengan jumlah penduduk relatif sedikit belum terlihat dampaknya terhadap kondisi lingkungan teluk.

Topografi daratan pulau-pulau yang terdapat di dalam teluk tersebut mulai dari datar sampai berbukit, posisi geografis berkisar antara $0545422 \mathrm{mT}$ $0577079 \mathrm{mU}$ sampai $8868048 \mathrm{mT}$ - $8891940 \mathrm{mU}$, sedangkan untuk seluruh kawasan penelitian, dasar perairan umumnya mempunyai tingkat kemiringan rata-rata mencapai $45^{\circ}$, kedalaman air berkisar 3,5$52,0 \mathrm{~m}$; salinitas $35-36 \mathrm{ppt}$; suhu air $27,0-28,1^{\circ} \mathrm{C}$; dan substrat dasar perairannya terdiri atas pasir $(50 \%-79 \%)$, liat $(0 \%-7 \%)$, dan debu $(21 \%-48 \%)$, sehingga dapat dikategorikan dalam kelas tekstur lempung berpasir sampai pasir berlempung dan pecahan karang $(100 \%)$.

Tipe pasang surut di sekitar Teluk Kupang yaitu pasang surut dengan komponen diurnal atau terjadi satu kali air pasang dan satu kali air surut dalam sehari dengan tunggang pasang di sekitar teluk $180 \mathrm{~cm}$.

Pada umumnya di Provinsi Nusa Tenggara Timur beriklim kering, di mana musim timur terjadi dari bulan April sampai dengan bulan November bertepatan dengan musim kemarau dan kondisi angin bertiup dari arah timur ke barat yang umumnya berkekuatan kecil 
sampai sedang. Musim barat terjadi dari bulan Desember sampai dengan Maret bertepatan dengan musim hujan dan kondisi angin bertiup dari arah barat ke timur yang umumnya berkekuatan besar. $\mathrm{Hal}$ ini menunjukkan bahwa musim kemarau terjadi lebih lama dari pada musim hujan sehingga angin yang bertiup lebih banyak dari arah timur ke barat yang berkekuatan kecil sampai sedang. Kondisi angin tersebut sangat berpengaruh terhadap pergerakan ombak dan arus di perairan Teluk Kupang.

Pola pergerakan arus permukaan yang masuk di perairan Teluk Kupang, di samping dipengaruhi oleh pola arus yang terjadi dari pecahan ombak di perairan Laut Timor, Sumba, dan Flores, juga oleh kondisi pasang surut di perairan Teluk Kupang dan sekitarnya. Kecepatan arus yang bergerak dari arah timur (Laut Timor dan Sumba) ke barat tertahan oleh Pulau Timor dan yang datang dari arah barat ke timur tertahan oleh Pulau Semau, Pulau Kambing, dan Pulau Burung, Dengan demikian arus yang berkekuatan besar di dalam perairan Teluk Kupang pada saat musim hujan hanya terjadi di wilayah tertentu seperti di Tanjung Manikin, Oesapa, dan Batuputih yang berlangsung selama 4 bulan mulai dari Desember sampai Maret setiap tahunnya.

Dengan melihat pola pergerakan arus dan ombak, lokasi yang potensial untuk pengembangan budi daya laut di perairan Teluk Kupang antara lain di kawasan perairan sebelah timur Pulau Semau, Pulau Kambing, dan Pulau Burung.

Menurut Ahmad et al. (1996), pengembangan usaha budi daya perikanan pesisir berbasis budi daya laut dapat dilakukan pada kawasan pesisir seperti selat, teluk, laguna, dan muara sungai yang terlindung dari pengaruh arus kuat, gelombang besar, angin yang kencang serta bebas cemaran. Selanjutnya menurut Cholik et al. (1995), ekosistem teluk, selat, goba, dan muara sungai umumnya merupakan lokasi bagi budi daya ikan, sedangkan dataran pasang surut yang landai dengan dasar batu-batuan, sisa-sisa karang, dan pasir dapat dijadikan lokasi bagi budi daya rumput laut. Lokasi yang baik bagi budi daya kekerangan umumnya adalah dataran pasang surut lumpur berpasir. Perairan estuarin juga baik bagi budi daya kekerangan seperti tiram dan kerang hijau.

\section{Potensi Kelayakan Lokasi Budi Daya Laut}

Satu di antara keberhasilan usaha budi daya laut diawali dengan pemilihan kelayakan lokasi dan luas lahan budi daya, menentukan estimasi jumlah unit keramba/rakit yang dapat tertampung di areal tersebut sesuai dengan komoditas yang dikelolanya dan daya dukung lahan. Dalam mengidentifikasi kebutuhan teknologi budi daya laut didasarkan pada karakteristik

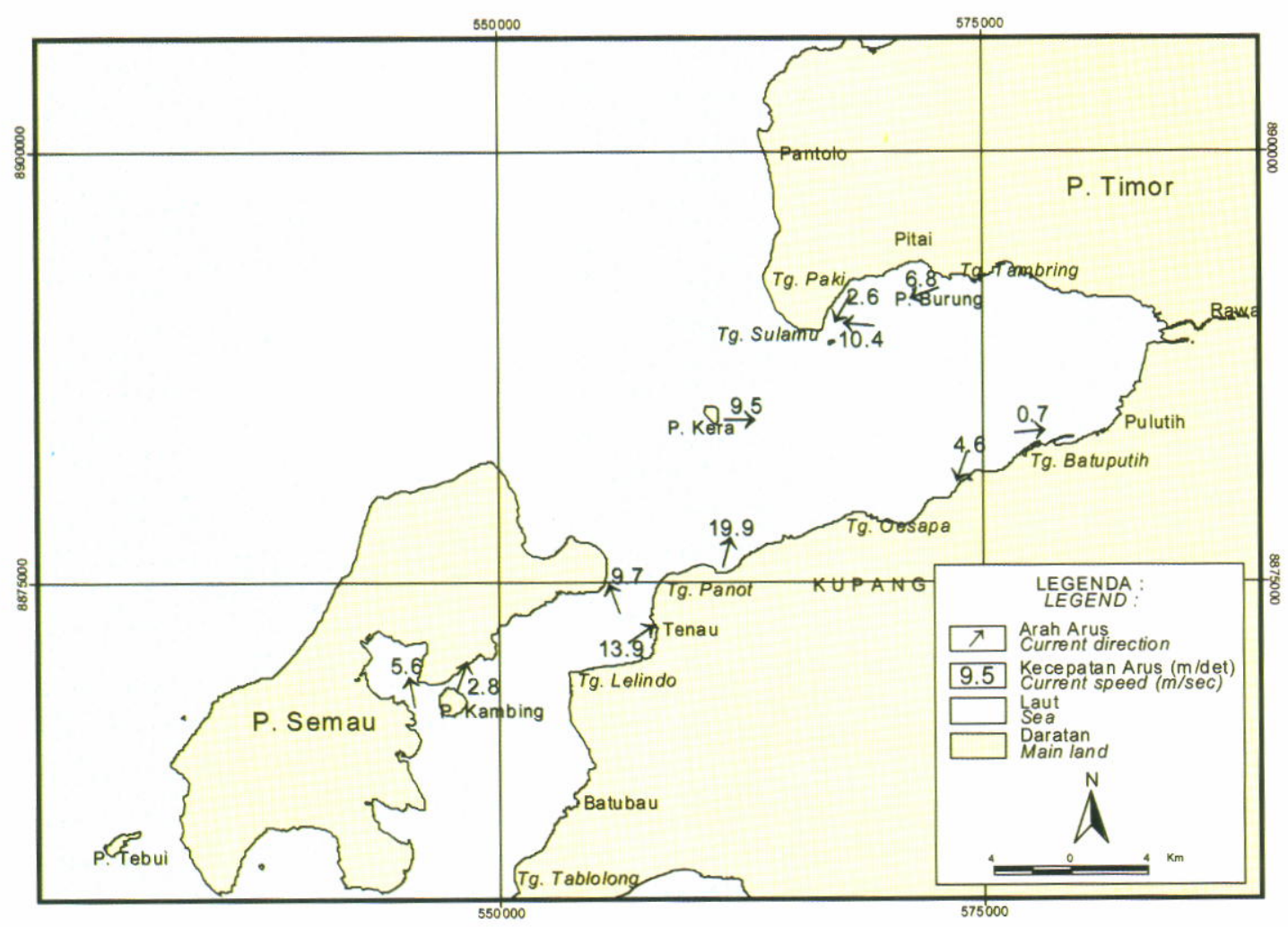

Gambar 3. Kisaran pergerakan arus di sekitar Teluk Kupang, Nusa Tenggara Timur Figure 3. Range of current movement in Kupang Bay, East Nusa Tenggara 
wilayah dan hasil survai fisik oseanografi serta mutu perairan Teluk Kupang.

Berdasarkan hasil survai fisik oseanografi dan mutu air pada bulan September dan November di perairan Teluk Kupang untuk potensi pengembangan budi daya laut terlihat pada Tabel 1.

Beberapa peubah fisik oseanografi yang sangat penting peranannya dalam menentukan lokasi budi daya antara lain gerakan ombak dan arus serta kedalaman. Gerakan ombak yang besar dengan pengaruh mekaniknya pada saat pelaksanaan budi daya dapat menghancurkan dan menghanyutkan konstruksi rakit, keramba, hampang, dan fasilitas penunjang lainnya. Pada saat musim timur yang bertepatan dengan musim penghujan tinggi ombak di perairan teluk berkisar $5-47 \mathrm{~cm}$ mempunyai kekuatan yang relatif kecil dengan periode berlangsungnya 8 bulan mulai dari April sampai dengan November, sedangkan pada saat musim barat yang bertepatan dengan musim kemarau pergerakan ombak berkekuatan besar dan berlangsungnya hanya 4 bulan mulai dari Desember sampai dengan Maret setiap tahunnya. Oleh karena adanya penghalang dari Pulau Timor bagian barat yang berdekatan dengan beberapa pulau antara lain Pulau Burung, Kambing, Kera, dan Semau, dapat menahan hidrodinamika perairan sehingga kondisi lokasi yang demikian cukup potensial digunakan untuk kegiatan budi daya laut.

MenurutAs'ad (2000), kekuatan ombak yang relatif kecil dapat menghantarkan gas-gas oksigen bebas dari atmosfer ke dalam air melalui proses defusi yang selanjutnya dapat meningkatkan kandungan oksigen terlarut dalam air dan dapat memberikan transfer energi melalui partikel air yang sesuai dengan arah hembusan. Menurut Ahmad et al. (1991), kondisi lingkungan seperti amplitudo pasang dan gelombang

Tabel 1. Hasil pengukuran fisik dan mutu air Teluk Kupang, Nusa Tenggara Timur

Table 1. Result of physical and water quality measurment of Kupang Bay, East Nusa Tenggara

\begin{tabular}{|c|c|c|c|}
\hline $\begin{array}{c}\text { Peubah fisik dan mutu air } \\
\text { Physical variables and water quality }\end{array}$ & $\begin{array}{l}\text { Satuan } \\
\text { Unit }\end{array}$ & $\begin{array}{l}\text { Kisaran nilai } \\
\text { Value range }\end{array}$ & $\begin{array}{l}\text { Nilai ideal } \\
\text { Ideal value }\end{array}$ \\
\hline Tinggi ombak (Wave hight) & $\mathrm{cm}$ & $5-47$ & $<50$ \\
\hline Kecepatan arus (Current) & $\begin{array}{l}\mathrm{cm} / \text { detik } \\
\mathrm{cm} / \mathrm{sec} \text {. }\end{array}$ & $0.7--19.9$ & $\begin{array}{c}\text { 5-10 Ikan (Fish) } \\
\text { 20-30 Rumput laut (Seaweed) }\end{array}$ \\
\hline Tunggang pasang surut (Tide) & $\mathrm{cm}$ & 180 & - \\
\hline Kedalaman (Depth) & $\mathrm{m}$ & $3.5-52.0$ & 10-15 Ikan (Fish) \\
\hline Substrat (Substrate): & $\%$ & & $\begin{array}{l}\text { 5--10 Rumput laut (Seaweed) } \\
\text { Pasir dan pecahan karang } \\
\text { (Sand and coral rubble) }\end{array}$ \\
\hline Pasir (Sand) & & $50--79$ & \\
\hline Lempung (Clay) & & $0--7$ & \\
\hline Debu (Silt) & & $21-48$ & \\
\hline Pecahan karang (Coral fragment) & & 100 & \\
\hline Derajat keasaman $(\mathrm{pH})$ & & 8.1--8.3 & $7.5-8.5$ \\
\hline Suhu (Temperature) & ${ }^{\circ} \mathrm{C}$ & $27.0--28.1$ & 27--32 \\
\hline Salinitas (Salinity) & $\mathrm{ppt}$ & $35--36$ & $30--35$ \\
\hline Kekeruhan (Turbidity) & NTU & $0--7.25$ & $<30$ \\
\hline Kecerahan (Transparency) & $\%$ & $52.5--100$ & $80-100(>5 \mathrm{~m})$ \\
\hline Oksigen terlarut (DO) (Dissolved oxygen) & $\mathrm{mg} / \mathrm{L}$ & $4.6-9.6$ & $>3$ \\
\hline $\mathrm{NH}_{3}-\mathrm{N}$ & $\mathrm{mg} / \mathrm{L}$ & $0.0212--0.0881$ & $<0.1$ \\
\hline $\mathrm{NO}_{2}-\mathrm{N}$ & $\mathrm{mg} / \mathrm{L}$ & $0.0070-0.0145$ & $<0.1$ \\
\hline $\mathrm{NO}_{3}-\mathrm{N}$ & $\mathrm{mg} / \mathrm{L}$ & $0.0109--0.8634$ & $0.9--3.2$ \\
\hline $\begin{array}{l}\mathrm{PO}_{4}-\mathrm{P} \\
\text { Logam berat (Heavy metal) : }\end{array}$ & $\mathrm{mg} / \mathrm{L}$ & 0.0217--0.0701 & $0.2--0.5$ \\
\hline Kadmium (Cadmium) (Cd) & & $0.0040--0.0048$ & $<0.01$ \\
\hline Tembaga (Cuprum) (Cu) & & $0.0006-0.0024$ & $<0.06$ \\
\hline Timbal (Plumbum) (Pb) & & $0.0040-0.0057$ & $<0.01$ \\
\hline Seng (Zinc) (Zn) & & $0.0004-0.0008$ & $<0.1$ \\
\hline
\end{tabular}


yang baik untuk usaha budi daya ikan dalam keramba jaring apung di laut kurang dari 2 meter.

Arus air yang berfungsi sebagai transportasi massa air sekaligus membersihkan kotoran, mendistribusikan kandungan oksigen terlarut dan unsur hara secara merata serta dapat mengurangi organisme penempel (fouling) sangat penting untuk menjaga media budi daya selalu dalam kondisi optimum. Kecepatan arus di perairan teluk berkisar $3,2-23,8 \mathrm{~cm} /$ detik dianggap relatif berkekuatan kecil hingga sedang karena arus pecah ombak yang bertepatan waktunya dengan musim hujan pada bulan Desember-Maret relatif singkat dan terhalang oleh beberapa pulau, sehingga kawasan teluk dan sekitarnya lebih banyak dipengaruhi oleh arus pasang surut yang gerakannya konstan. Lokasi yang demikian dinilai sebagai lahan perikanan pesisir yang potensial untuk usaha budi daya.

Menurut Ahmad et al. (1991), kecepatan arus yang baik untuk usaha budi daya ikan dalam keramba jaring apung berkisar $5-15 \mathrm{~cm} /$ detik. Selanjutnya lokasi yang diinginkan untuk budi daya rumput laut yaitu mempunyai gerakan air yang cukup untuk membawa unsur hara dengan kecepatan arus berkisar 20-40 $\mathrm{cm} /$ detik (Mubarak et al., 1990). Arah arus perlu diketahui untuk menentukan lay out wadah budi daya sehingga sirkulasi air tetap lancar dan terkendali.

Menurut Mayunar et al. (1995), untuk usaha budi daya ikan dalam keramba jaring apung, desain dan konstruksi keramba harus disesuaikan dengan kecepatan arus dan kondisi dasar perairan (lumpur, pasir, atau karang).

Kedalaman air yang sangat dipengaruhi oleh perubahan pasang dan kontur dasar perairan sangat penting peranannya dalam menentukan metode budi daya yang diterapkan dan komoditas yang dikelola. Kedalaman air di teluk berkisar 3,5-52,0 m. Nilai kisaran kedalaman pada kawasan tersebut masih dalam batas potensial dikembangkan untuk berbagai metode budi daya.

Untuk usaha budi daya yang menggunakan keramba jaring apung memerlukan jarak paling sedikit $5 \mathrm{~m}$ dari keramba ke dasar perairan (Sunyoto, 1994). Menurut Ahmad et al. (1991), kedalaman air laut yang layak untuk kegiatan budi daya ikan dalam keramba jaring apung lebih dari $5 \mathrm{~m}$. Usaha budi daya menggunakan jaring tancap (lola) memerlukan kedalaman sekitar $0,5 \mathrm{~m}$ pada saat surut terendah.

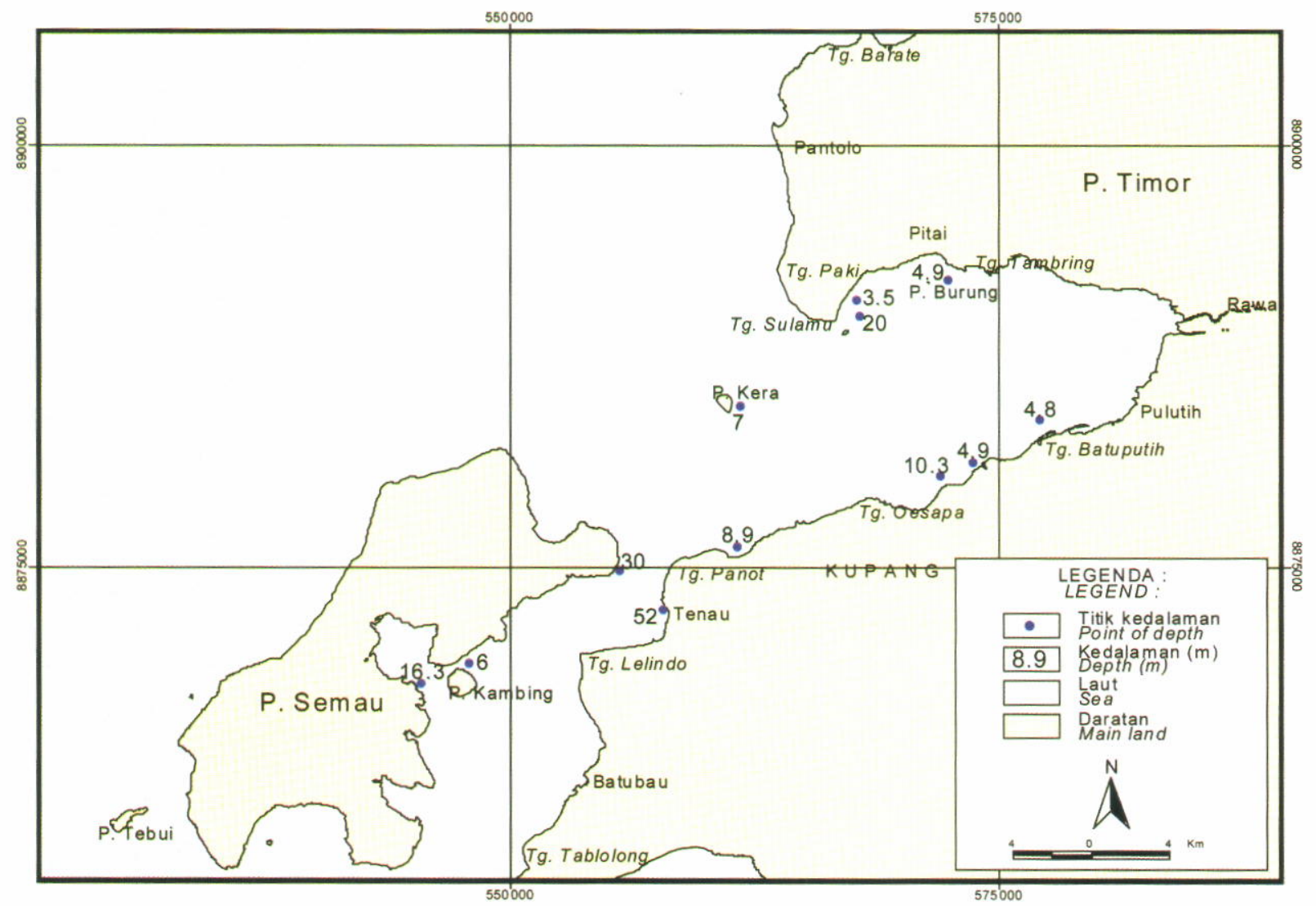

Gambar 4. Kisaran kedalaman perairan di sekitar Teluk Kupang, Nusa Tenggara Timur Figure 4. Range of water depth in Kupang Bay, East Nusa Tenggara 
Dengan demikian kisaran kedalaman yang terukur di daerah ini potensial dikembangkan untuk usaha budi daya ikan dalam keramba jaring apung, budi daya kekerangan dalam jaring tancap atau hampang, dan budi daya rumput laut dengan menggunakan rakit terapung.

Mutu air laut sebagai media budi daya, kondisinya selalu berfluktuasi tergantung atau sangat dipengaruhi oleh perubahan pasang dan musim. Peubah media budi daya yang lama berpengaruh terhadap kondisi perairan laut adalah logam berat karena merupakan pencemar atau limbah dari industri yang dapat terakumulasi di dalam badan komoditas budi daya, lingkungan, dan dasar perairan. Kisaran nilai peubah media budi daya di perairan teluk, terutama logam berat yang terdiri atas unsur kadmium $(\mathrm{Cd})$ berkisar $0,0040-0,0048 \mathrm{mg} / \mathrm{L}$; tembaga $(\mathrm{Cu}) 0,0006-0,0024$ $\mathrm{mg} / \mathrm{L}$, timbal $(\mathrm{Pb})$ 0,0040-0,0057 $\mathrm{mg} / \mathrm{L}$, dan seng (Zn) 0,0004-0,0008 $\mathrm{mg} / \mathrm{L}$, masih aman dan memenuhi syarat untuk kegiatan budi daya laut sesuai yang dianjurkan oleh Kementerian Kependudukan dan Lingkungan Hidup (KLH) (1988) yaitu unsur kadmium (Cd) yang diperbolehkan lebih kecil dari $0,01 \mathrm{mg} / \mathrm{L}$; untuk unsur tembaga $(\mathrm{Cu}$ ) yang diperbolehkan lebih kecil $0,06 \mathrm{mg} / \mathrm{L}$; dan untuk unsur seng $(\mathrm{Zn})$ yang diperbolehkan lebih kecil $0,1 \mathrm{mg} / \mathrm{L}$; serta untuk unsur timbal $(\mathrm{Pb})$ yang diperbolehkan lebih kecil 0,01 $\mathrm{mg} / \mathrm{L}$.

Hasil analisis tekstur tanah di dasar perairan teluk terdiri atas pasir $(50 \%-79 \%)$, lempung $(0 \%-7 \%)$, debu $(21 \%-48 \%)$, dan pecahan karang $(100 \%)$. Jenis tekstur tanah di dasar peráiran teluk didominasi oleh pecahan karang, pasir berlempung, dan lempung berpasir. Sedimen tersebut merupakan material fragmental yang terjadi akibat hancurnya batuan karang dan bahan-bahan organik yang terendapkan oleh tenaga air dan angin (Setiono, 1996). Substrat dasar tersebut merupakan salah satu indikator habitat dari ikan karang, rumput laut, dan teripang, sehingga kondisi yang demikian ini cukup potensial untuk lokasi budi daya laut. Substrat dasar juga berpengaruh terhadap kemudahan pemasangan fasilitas budi daya, produktivitas perairan, ketersediaan pakan alami, kekeruhan, dan sedimentasi.

Menurut Mayunar et al. (1995), perairan tempat keramba jaring apung sebaiknya bertopografi landai, kedalaman 6-8 memiliki dasar pasir berlumpur atau lumpur berpasir, airnya jernih, dan terhindar dari pelumpuran (siltasi) karena dapat mempengaruhi bobot jaring, mutu air, dan usaha budi daya. Untuk budi daya rumput laut memerlukan substrat dasar liat berpasir dan karang dengan pergerakan air lancar, kecerahan tinggi, fosfat, silikat, salinitas, dan oksigen terlarut tinggi, sedangkan untuk budi daya teripang memerlukan substrat dasar pasir berlumpur, lumpur berpasir atau liat berpasir yang ditumbuhi lamun dan ganggang serta detritus yang memadai (Tiensongrusmee, 1989).

Jenis plankton yang merupakan bagian dari media budi daya di perairan teluk terdiri atas 14 spesies fitoplankton dan 2 spesies zooplankton. Kelimpahan fitoplankton yang tertinggi (45-740 ind. $/ \mathrm{mL}$ ) diperoleh dari Acartia sp., kemudian Pleurosigma sp. (60-405 ind. $/ \mathrm{mL})$, Chaetoceros sp. (30-540 ind. $/ \mathrm{mL})$, dan Nitzschia sp. (65-535 ind./mL). Populasi fitoplankton tersebut terdapat di semua stasiun pengamatan. Kelimpahan zooplankton yang tertinggi didominasi oleh Brachionus sp. (25-1.690 ind. $/ \mathrm{mL})$, sedangkan yang terendah yaitu Cladocera sp. (20-175 ind./mL). Pada dasarnya peranan organisme plankton penting artinya dalam penilaian terhadap kondisi perairan dan potensi sumber daya lautnya terutama untuk pengembangan kegiatan budi daya kekerangan. Apabila kelimpahan fitoplankton terlalu tinggi (blooming) merupakan indikasi cemaran biologis perairan.

Dari hasil penilaian tingkat kelayakan lokasi budi daya laut (ikan, rumput laut, dan kekerangan) yang letaknya tersebar di sekitar Teluk Kupang menunjukkan bahwa sumber daya lahan perikanan pesisir yang potensial dikembangkan untuk budi daya laut seluas $2.849,1$ hektar dapat dilihat pada Gambar 5.

Lokasi yang potensial dikembangkan untuk budi daya ikan dalam keramba jaring apung terdapat di sekitar Pulau Burung seluas 439,5 hektar; Pulau Semau dan Pulau Kambing seluas 483,1 hektar. Lokasi yang potensial dikembangkan untuk budi daya rumput laut terdapat di sekitar Pulau Burung (592,3 hektar), Pulau Semau dan Pulau Kambing (1.038 hektar). Lokasi yang potensial dikembangkan untuk budi daya kerang mutiara terdapat di sebelah timur Pulau Semau (296,2 hektar).

Untuk pengembangan usaha budi daya laut yang ramah lingkungan dan berkelanjutan, maka potensi yang ada sekiranya tidak dimanfaatkan seluruhnya, harus disediakan untuk kawasan penyangga dan aktivitas perikanan lainnya. Teluk Kupang dengan luasan potensial untuk budi daya ikan dalam keramba jaring apung 920 hektar hanya dapat dimanfaatkan sebesar $10 \%$ yaitu seluas 92 hektar (Hanafi et al., 2001). Dengan pertimbangan bahwa setiap hektar lahan budi daya ikan dalam keramba jaring apung dapat ditempatkan rakit secara efektif sebanyak 50 unit dan setiap rakitnya terdiri atas 4 unit keramba berukuran $2 \times 2 \times 2 \mathrm{~m}^{3}$. Dengan luasan potensial 1.630 hektar untuk budi daya rumput laut dapat dimanfaatkan hanya 163 hektar, dengan pertimbangan bahwa setiap hektar lahan budi daya rumput laut dapat ditempatkan rakit secara efektif sebanyak 100 unit yang setiap rakitnya berukuran $5 \times 2,5 \mathrm{~m}^{2}$. Dengan 


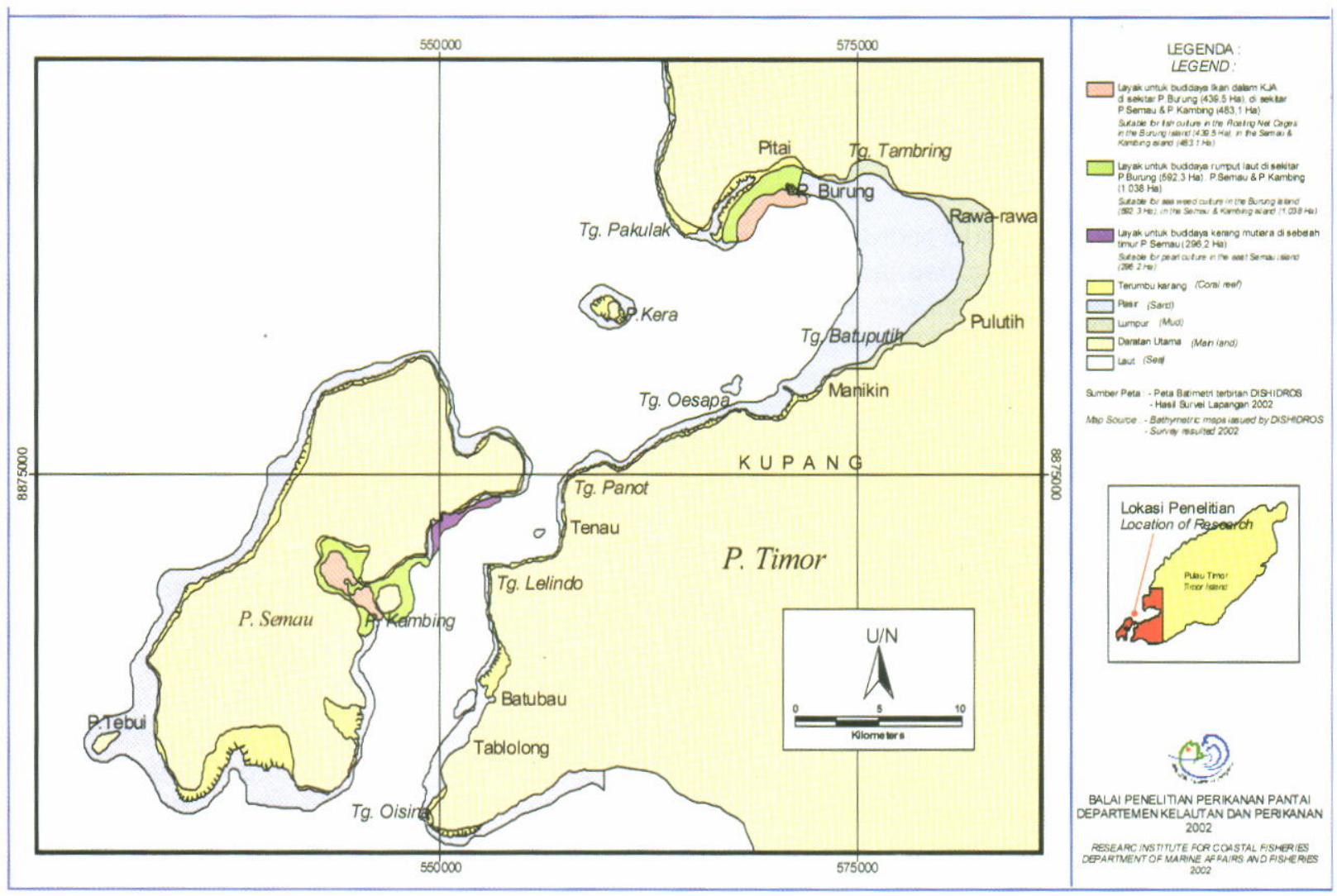

Gambar 5. Peta kelayakan lahan budi daya laut di sekitar Teluk Kupang, Nusa Tenggara Timur Figure 5. Map of suitable area for mariculture in Kupang Bay, East Nusa Tenggara

luasan potensial 296 hektar untuk budi daya kerang mutiara dapat dimanfaatkan hanya 29 hektar, dengan pertimbangan bahwa setiap hektar lahan budi daya kerang mutiara dapat ditempatkan rakit secara efektif sebanyak 100 unit yang setiap rakitnya berukuran 4 $\times 2 \mathrm{~m}^{2}$.

\section{Prioritas Tahapan Kegiatan Usaha Budi Daya Laut yang Akan Diaplikasikan}

Sebagai tahapan awal yang mudah dan segera dapat dikerjakan atau diperkenalkan adalah budi daya rumput laut jenis Eucheuma sp. sebagai bahan untuk pembuatan karaginan ataupun jenis Gracilaria sp. sebagai bahan pembuatan agar-agar. Metode budi dayanya cukup murah dan mudah yaitu dengan metode apung (raft method) menggunakan rakit atau tali gantung (kedalaman teluk 3,5-52,0 m) dengan investasi yang terjangkau dan dapat diadopsi dengan baik oleh masyarakat nelayan. Berdasarkan tingkat produktivitas yang tinggi sekitar $20 \mathrm{~kg}$ rumput laut kering/ rakit $\left(5 \times 2,5 \mathrm{~m}^{2}\right)$ dan siklus periode pemeliharaan yang relatif singkat sekitar 45 hari setelah tanam, maka rumput laut dapat dikembangkan dengan mudah.

Untuk memperkuat pengembangan usaha rumput laut sebaiknya dilakukan dengan membentuk usaha secara berkelompok seperti Kelompok Usaha Bersama (KUB) atau koperasi yang diharapkan dapat mendorong tumbuhnya industri pasca panen (industri menengah) yang dapat merangsang berkembangnya industri hulu (backward linkage) dan industri hilir (forward linkage).

Memperkuat lembaga sosial ekonomi petani rumput laut dengan melibatkan petani tersebut sebagai subjek dalam pembangunan agribisnis melalui pengembangan kemitraan antara kelompok tani rumput laut dengan pengusaha diharapkan terjadi peningkatan kualitas dalam manajemen usaha, kemampuan dalam mengakses modal dan teknologi serta merespon perluasan jaringan pemasaran (networking) baik di dalam negeri maupun luar negeri. Dengan mempertimbangkan peluang yang ada, maka bila setiap rumah tangga nelayan memiliki 10 unit rakit $\left(5 \times 2,5 \mathrm{~m}^{2}\right)$ dengan jumlah frekuensi tanam sebanyak 8 musim setahun dan harga jual Rp 3.000,-/kg kering, maka setiap keluarga nelayan akan memperoleh pendapatan sebanyak Rp 4.800.000,-/tahun atau Rp $400.000,-/$ bulan, suatu usaha yang cukup layak sebagai sumber pendapatan masyarakat nelayan. Selain budi daya rumput laut, juga dapat diusahakan budi daya kekerangan (tiram, abalon, kerang darah, 
dan kerang mutiara) dengan metode dasar (bottom method), metode hampang ( $p$ en culture), dan metode apung (raft method)

Tahapan berikutnya (kedua) adalah usaha budi daya laut yang memerlukan modal lebih besar dan pengetahuan yang lebih luas, yaitu budi daya ikan menggunakan keramba jaring apung (KJA). Dibutuhkan modal lebih besar, karena selain untuk pembuatan rakit dan keramba jaring, juga dibutuhkan pengeluaran biaya untuk pakan. Komoditas yang dipelihara dalam KJA harus ekonomis penting seperti ikan kerapu (Epinephelus sp.), baronang (Siganus sp.), dan Napoleon (Cheilinus undulatus).

\section{KESIMPULAN}

Sumber daya lahan perikanan pesisir di Teluk Kupang, yang potensial dikembangkan untuk budi daya laut seluas $2.849,1$ hektar. Penilaian sumber daya lahan tersebut tergolong layak untuk lokasi budi daya ikan, rumput laut, dan kekerangan. Kondisi oseanografi perairan lautnya sebagai media budi daya masih layak, aman, dan mendukung kegiatan budi daya.

\section{UCAPAN TERIMA KASIH}

Ucapan terima kasih ditujukan kepada Sdri. Sutrisyani yang telah membantu dalam menganalisis mutu air pada pelaksanaan penelitian ini.

\section{DAFTAR PUSTAKA}

Ahmad, T., P.T. Imanto, Muchari, A. Basyarie, P. Sunyoto, B. Slamet, Mayunar, R. Purba, S. Diana, S. Redjeki, S.A. Pranowo, dan S. Murtiningsih. 1991. Operasional Pembesaran Ikan Kerapu dalam Keramba Jaring Apung. Balai Penelitian Perikanan Budidaya Pantai. Pusat Penelitian dan Pengembangan Perikanan. Departemen Pertanian, 59 pp.

Ahmad, T., A. Mustafa, dan A. Hanafi. 1996. Konsep pengembangan desa pantai mendukung keberlanjutan produksi perikanan pesisir. Dalam Poernomo, A., H.E. Irianto, S. Nurhakim, Murniyati, dan E. Pratiwi (Eds.). Prosiding Rapat Kerja Teknis Peningkatan Visi Sumberdaya Manusia Peneliti Perikanan Menyongsong Globalisasi IPTEK, Serpong, 19-20 November 1996. Badan Litbang Pertanian, Puslitbang Perikanan, Jakarta, p. 91-106.

Ahmad, T., A. Rukyani, dan A. Wijono. 1995. Teknik budidaya laut dengan keramba jaring apung. Dalam Sudradjat, A., W. Ismail, B. Priono, Murniyati, dan E. Pratiwi (Eds.). Prosiding Temu Usaha Pemasyarakatan Teknologi Keramba Jaring Apung Bagi Budidaya Laut, Jakarta, 12-13 April 1995. Badan Litbang Pertanian, Puslitbang Perikanan, Jakarta, p. 69-87.

Anonim. 2000. Kupang dalam Angka (Kupang in Figures). Kerja Sama Badan Pusat Statistik
Kabupaten Kupang dan BAPPEDA Kabupaten Kupang, Nusa Tenggara Timur, 332 pp. Anonim. 1999. Pedoman Analisis SWOT. Proyek Pengkajian Teknologi Pertanian Partisipatif. Badan Penelitian dan Pengembangan Pertanian, Jakarta, $17 \mathrm{pp}$

Anonim. 1999. Pedoman analisis SWOT. Proyek Pengkajian Teknologi Pertanian Partisipatif. Badan Penelitian dan Pengembangan Pertanian, Jakarta, $17 \mathrm{pp}$.

As'ad, M. 2000. Abrasi pantai Biringkasi. Maccini Baji, Kecamatan Bungoro, Labakkang Kabupaten Pangkep. Skripsi Jurusan IImu Kelautan, Fakultas IImu Kelautan dan Perikanan, Universitas Hasanuddin, Makassar, $70 \mathrm{pp}$.

Atjo, H. 1992. Potensi sumberdaya kekerangan Kabupaten Baru. Dalam Mansur, H., Rachmansyah, A. Mustafa, dan A.M. Pirzan (Eds.). Prosiding Temu Karya IImiah Potensi Sumber Daya Kekerangan Sulawesi Selatan dan Sulawesi Tenggara. No.7, 1992, Watampone, 17-18 Februari 1992, p. 8-10.

Clark, W.A.V. and P.L. Hosking. 1986. Statistical Methods for Geographers. John Wiley \& Sons, Inc., 513 pp.

Cholik, F., A. Sudradjat, dan P.T. Imanto. 1995. Peluang agribisnis budidaya laut di kawasan Timur Indonesia. Dalam A. Sudradjat, W. Ismail, B. Priono, Murniyati, dan E. Pratiwi (Eds.). Prosiding Temu Usaha Pemasyarakatan Teknologi Keramba Jaring Apung Bagi Budidaya Laut, Jakarta, 12-13 April 1995. Badan Litbang Pertanian, Jakarta, p.136-156.

Hanafi, A., Tarunamulia, A. Rachman, dan T. Ahmad. 2001. Penataan ruang Teluk Pegametan di Kecamatan Gerokgak, Bali untuk pengembangan sea farming. Dalam Sudradjat et al. (Eds.). Teknologi Budidaya Laut dan Pengembangan Sea Farming di Indonesia. Pusat Penelitian dan Pengembangan Eksplorasi Laut dan Perikanan, p. 57-69.

Hidayat, A., M. Soekardi, dan Ponidi. 1995. Kajian kesesuaian lahan untuk mendukung pembangunan perikanan pantai dan pertanian di daratan KasiputeLainea, Sulawesi Tenggara. Dalam Laporan Akhir Hasil Penelitian Potensi dan Hasil Kesesuaian Lahan untuk Pengembangan Perikanan Pantai (Tingkat Tinjau Mendalam) Daerah Kasipute-Lainea, Sulawesi Tenggara. Pusat Penelitian Tanah dan Agroklimat Bekerjasama dengan Proyek Pembinaan Kelembagaan Penelitian Pertanian Nasional, Jakarta, p. 96-162.

Kependudukan dan Lingkungan Hidup (KLH). 1988. Surat Keputusan Menteri Negara Kependudukan dan Lingkungan Hidup No. KEP-02/MENKLH/I/1998, tanggal 19 Januari 1988 tentang Baku Mutu Air untuk Perikanan dan Taman Laut Konservasi. Lampiran VII dan VIII.

Mayunar, R. Purba, dan P.T. Imanto. 1995. Pemilihan lokasi untuk usaha budidaya ikan laut. Dalam Sudradjat, A., W. Ismail, B. Priono, Murniyati, dan E. Pratiwi (Eds.). Prosiding Temu Usaha Pemasyarakatan Teknologi Keramba Jaring Apung bagi Budidaya Laut, Jakarta, 12-13 April 1995, p. 179-189 
Morain, S. 1999. GIS Solution in Natural Resource Management: Balancing the Technical-Political Equation. On Word Press. USA, $361 \mathrm{pp}$.

Mubarak, H., S. Ilyas, W. Ismail, I.S. Wahyuni, S.H. Hartati, E. Pratiwi, Z. Jangkaru, dan R. Arifuddin. 1990. Petunjuk Teknis Budidaya Rumput Laut. Badan Litbang Pertanian, Puslitbang Perikanan, IDRC, Infish, $93 \mathrm{pp}$.

Purwadhi, S. Hardiyanti, Susanto, dan Hidayat. 1997. Penggunaan data inderaja satelit dan sistem informasi geografis (SIG) untuk perencanaan dan pengelolaan tata ruang wilayah. Dipresentasikan dalam Seminar Open House LAPAN dalam rangka Tahun Kebangkitan IPTEK Nasional, Jakarta. 5-7 Agustus 1997.

Setiono, H. 1996. Kamus Oseanografi. Gadjah Mada University Press, Yogyakarta.

Sunyoto, P. 1994. Pembesaran Kerapu dengan Keramba Jaring Apung. Penebar Swadaya, Jakarta, 65 pp.

Tiensongrusmee, B., S. Pontjoprawiro, and K. Mintardjo. 1989. Seafarming Resources. Map. INS/81/008/ MANUAL/7. 


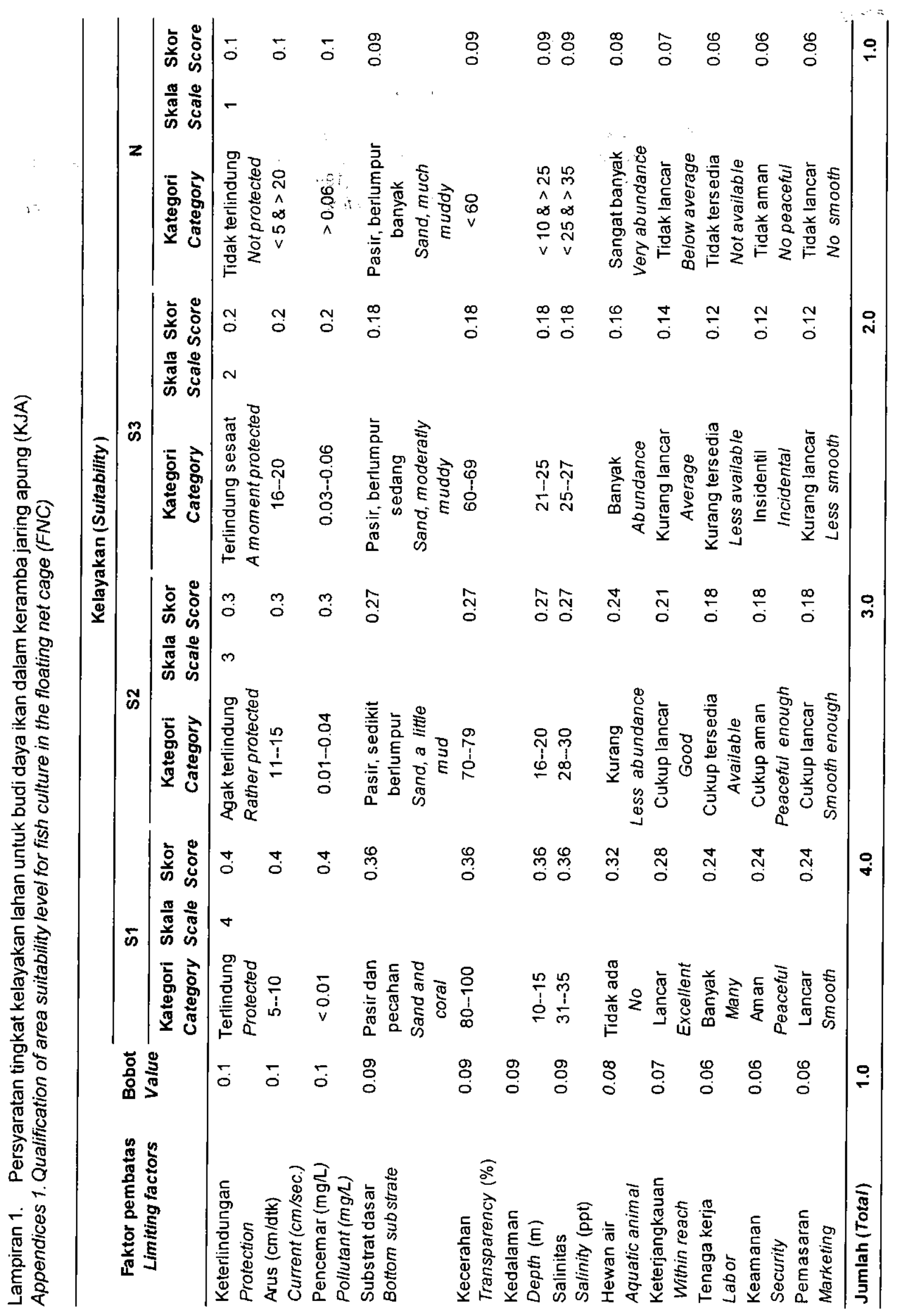




\section{Keterangan (Remark):}

Nilai (Value): $(100 \%)$

$(75 \%-99 \%)$

$(50 \%-74 \%)$

$(<50 \%)$
= $\quad$ sangat sesuai (very suitable) (S1)

$=\quad$ sesuai (suitable) (S2)

= cukup sesuai: dapat diterima bila peubah yang buruk dapat diperbaiki (suitable enough: can be accepted if the bad variable can be corrected (S3)

= $\quad$ kurang sesuai: tidak dapat diterima (less suitable, can not be accepted) (N) Kelayakan lahan untuk budi daya ikan dalam KJA mengacu pada persyaratan yang disarankan oleh Ahmad et al. (1991)

Area suitability for fish culture in the floating net cages according by Ahmad et al. (1991) 


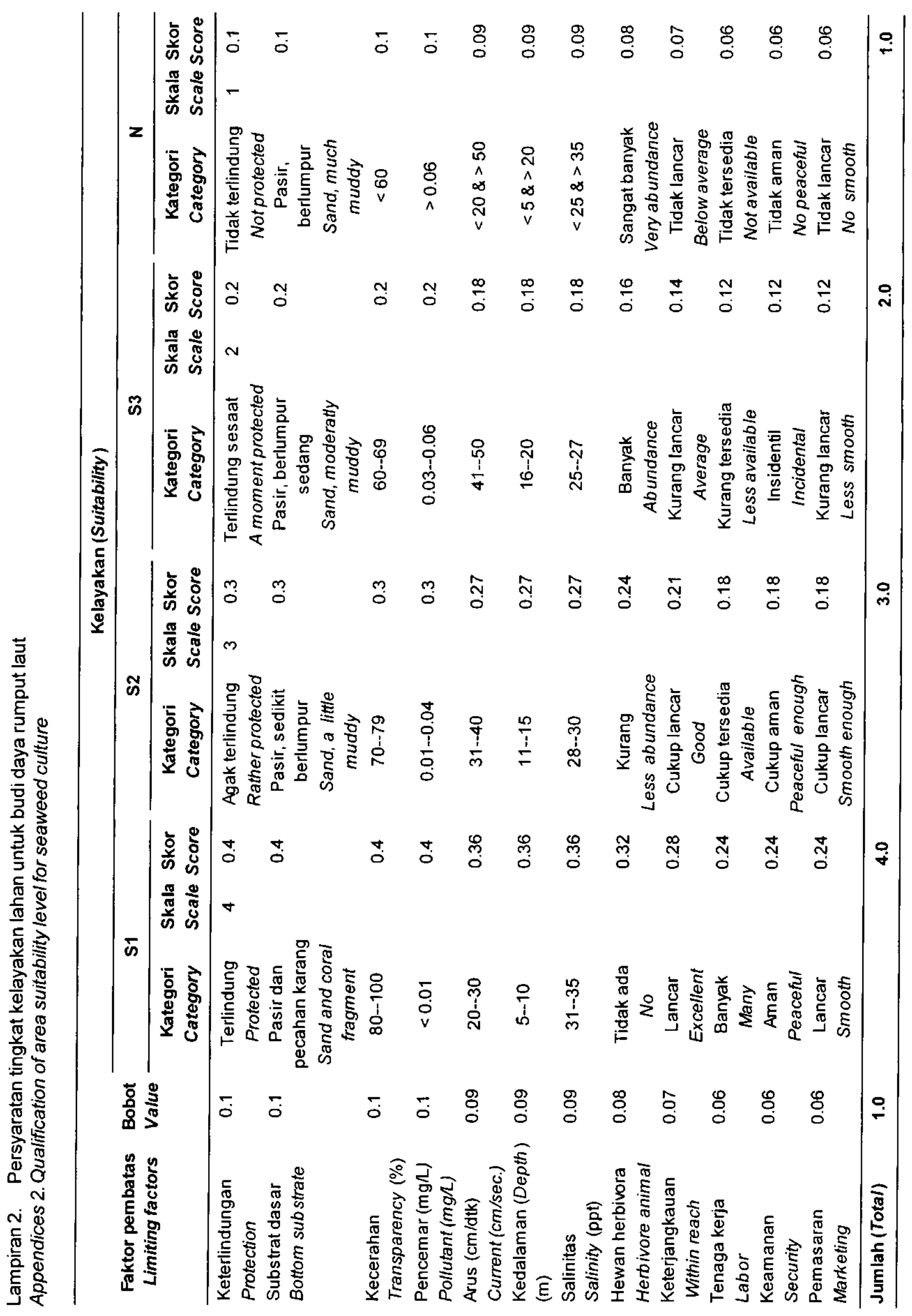


Keterangan (Remark):

Nilai (Value):

(100\%)

$=\quad$ sangat sesuai (very suitable) (S1)

$(75 \%-99 \%)$

$=\quad$ sesuai (suitable) (S2)

$(50 \%-74 \%$

$=$

$(<50 \%)$ cukup sesuai: dapat diterima bila peubah yang buruk dapat diperbaiki (suitable enough: can be accepted if the bad variable can be corrected (S3)

= $\quad$ kurang sesuai: tidak dapat diterima (less suitable, can not be accepted) $(\mathrm{N}$ ) Kelayakan lahan untuk budi daya rumput laut mengacu pada persyaratan yang disarankan oleh Mubarak et al. (1990)

Area suitability for seaweed culture according by Mubarak et al. (1990) 


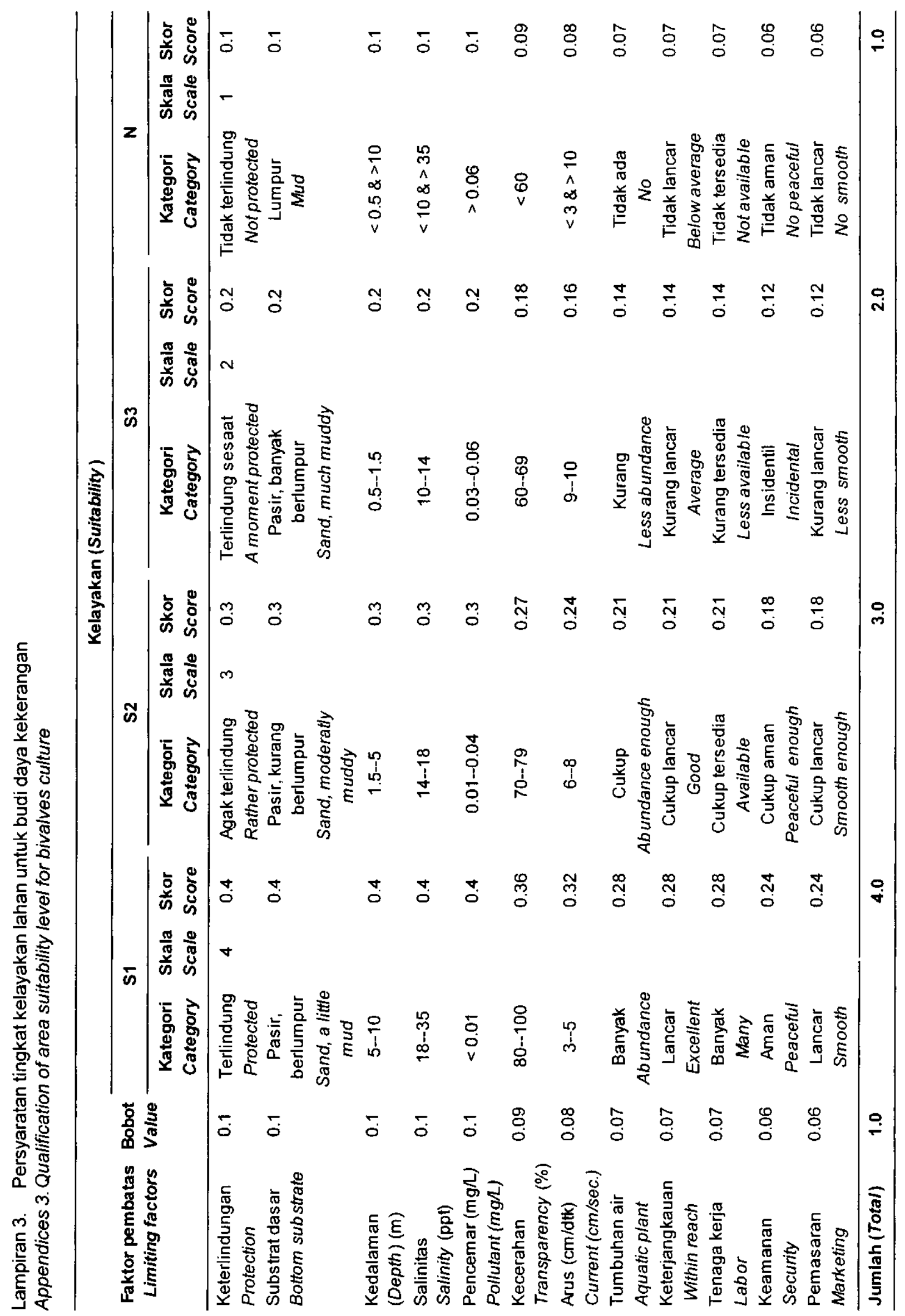


Utojo, Mansyur, A., Tarunamulia, Pantjara, B., dan Hasnawi

Keterangan (Remark):

Nilai (Value):

$(100 \%)$

$(75 \%-99 \%)$

$(50 \%-74 \%)$

= $\quad$ sangat sesuai (very suitable) (S1)

$=\quad$ sesuai (suitable) (S2)

= cukup sesuai: dapat diterima bila peubah yang buruk dapat diperbaiki (suitable enough: can be accepted if the bad variable can be corrected (\$3)

$(<50 \%)$

= kurang sesuai: tidak dapat diterima (less suitable, can not be accepted) (N) Kelayakan lahan untuk budi daya kekerangan mengacu pada persyaratan yang disarankan oleh Atjo (1992) dan Ahmad et al. (1991)

Area suitability for bivalves culture according by Atjo (1992) and Ahmad et al. (1991) 
Lampiran 4. Hasil pengukuran fisik dan mutu air Teluk Kupang, Nusa Tenggara Timur Appendices 4. Results of physical and water quality measurement of Kupang Bay, East Nusa Tenggara

\begin{tabular}{|c|c|c|c|c|c|c|c|c|}
\hline $\begin{array}{l}\text { Kode } \\
\text { lokasi } \\
\text { Location } \\
\text { code (St) }\end{array}$ & $\begin{array}{c}\text { Posisi } \\
\text { Geografis } \\
\text { Geographycal } \\
\text { Position (UTM) }\end{array}$ & $\begin{array}{c}\text { Kecepatan } \\
\text { arus } \\
\text { (cm/detik) } \\
\text { Current } \\
(\mathrm{cm} / \mathrm{sec} \text { ) }\end{array}$ & $\begin{array}{c}\text { Kedalaman } \\
\text { Depth }(\mathrm{m})\end{array}$ & $\begin{array}{c}\text { Kecerahan } \\
\text { Transparency } \\
(\%)\end{array}$ & $\begin{array}{l}\text { Kekeruhan } \\
\text { Turbidity } \\
\text { (NTU) }\end{array}$ & $\begin{array}{c}\text { Pasir } \\
\text { Sand } \\
(\%)\end{array}$ & $\begin{array}{l}\text { Liat } \\
\text { Clay } \\
(\%)\end{array}$ & $\begin{array}{c}\text { Debu } \\
\text { Silt } \\
(\%)\end{array}$ \\
\hline St1 & $\begin{array}{l}0571992 \\
8880331\end{array}$ & 5.2 & 10.3 & 63.1 & 3.51 & 54 & 0 & 46 \\
\hline St2 & $\begin{array}{l}0573712 \\
8881155\end{array}$ & 4.6 & 4.9 & 65.3 & 2.8 & 60 & 6 & 34 \\
\hline St3 & $\begin{array}{l}0577079 \\
8883706\end{array}$ & 0.7 & 4.8 & 71.4 & 3.05 & 50 & 4 & 46 \\
\hline St4 & $\begin{array}{l}0572446 \\
8891940\end{array}$ & 6.8 & 4.9 & 81.6 & 2.37 & 50 & 2 & 48 \\
\hline St5 & $\begin{array}{l}0567734 \\
8890803\end{array}$ & 2.6 & 3.5 & 88.6 & 1.31 & 74 & 0 & 26 \\
\hline St6 & $\begin{array}{l}0567875 \\
8889793\end{array}$ & 10.4 & 20 & 72.5 & 1.25 & 60 & 5 & 35 \\
\hline St7 & $\begin{array}{l}0561744 \\
8884488\end{array}$ & 9.5 & 7 & 100 & 0.28 & 70 & 0 & 30 \\
\hline St8 & $\begin{array}{l}0561601 \\
8876164\end{array}$ & 19.9 & 8.9 & 100 & 0 & 52 & 7 & 41 \\
\hline St9 & $\begin{array}{l}0555553 \\
8874720\end{array}$ & 9.7 & 30 & 66.7 & 0.49 & 58 & 0 & 42 \\
\hline St10 & $\begin{array}{l}0547813 \\
8869224\end{array}$ & 2.8 & 6 & 80 & 0.17 & 79 & 0 & 21 \\
\hline St11 & $\begin{array}{l}0545422 \\
8868048\end{array}$ & 5.6 & 16.3 & 75.3 & 0.2 & 55 & 5 & 40 \\
\hline St12 & $\begin{array}{l}0557826 \\
8872397\end{array}$ & 13.9 & 52 & 52.5 & 7.25 & - & - & - \\
\hline
\end{tabular}

\section{Keterangan (Remark):}

St : $\quad$ Lokasi pengamatan (Observation location)

UTM : $\quad$ Universal Transverse Merecator (satuan posisi geografis/value of geographycal position)

Pengambilan sampel air pada kedalaman $4 \mathrm{~m}$ (Water sampling at water depth of $4 \mathrm{~m}$ )

Substrat dasar perairan Teluk Kupang (\%): pasir, liat, dan debu (Bottom substrate of Kupang Bay (\%): sand, clay, and silt) 
Lanjutan lampiran 4. Hasil pengukuran fisik dan mutu air Teluk Kupang, Nusa Tenggara Timur Appendices 4. Results of physical and water quality measurement of Kupang Bay, East Nusa Tenggara

\begin{tabular}{|c|c|c|c|c|c|c|c|c|}
\hline $\begin{array}{l}\text { Kode } \\
\text { lokasi } \\
\text { Location } \\
\text { code }\end{array}$ & $\begin{array}{c}\text { Suhu } \\
\text { Temperature } \\
\left({ }^{\circ} \mathrm{C}\right)\end{array}$ & $\begin{array}{c}\text { Salinitas } \\
\text { Salinity } \\
(\mathrm{mg} / \mathrm{L})\end{array}$ & $\mathrm{pH}$ & $\begin{array}{c}\text { Oksigen } \\
\text { terlarut } \\
\text { Dissolved } \\
\text { oxygen } \\
\text { (mg/L) }\end{array}$ & $\begin{array}{l}\mathrm{NH} 3-\mathrm{N} \\
\text { (mg/L) }\end{array}$ & $\begin{array}{l}\mathrm{NO} 2-\mathrm{N} \\
(\mathrm{mg} / \mathrm{L})\end{array}$ & $\begin{array}{l}\text { NO3-N } \\
\text { (mg/L) }\end{array}$ & $\begin{array}{l}\text { PO4-P } \\
\text { (mg/L) }\end{array}$ \\
\hline St1 & 27.1 & 36 & 8.1 & 6.9 & 0.0488 & 0.0110 & 0.4421 & 0.0239 \\
\hline St2 & 27.4 & 36 & 8.2 & 7.5 & 0.0655 & 0.0105 & 0.8634 & 0.0217 \\
\hline St3 & 28.1 & 35 & 8.2 & 4.6 & 0.0225 & 0.0119 & 0.5850 & 0.0428 \\
\hline St4 & 27.7 & 35 & 8.2 & 7.9 & 0.0368 & 0.0128 & 0.3798 & 0.0249 \\
\hline St5 & 27.9 & 36 & 8.3 & 8.1 & 0.0881 & 0.0101 & 0.0213 & 0.0347 \\
\hline St6 & 27.3 & 35 & 8.2 & 7.6 & 0.0413 & 0.0110 & 0.0109 & 0.0396 \\
\hline St7 & 27.8 & 35 & 8.2 & 9.6 & 0.0454 & 0.0101 & 0.5131 & 0.0374 \\
\hline St8 & 27.4 & 35 & 8.2 & 7.8 & 0.0505 & 0.0122 & 0.6540 & 0.0413 \\
\hline St9 & 27.9 & 35 & 8.3 & 6.9 & 0.0212 & 0.0145 & 0.4716 & 0.0372 \\
\hline St10 & 27.7 & 35 & 8.3 & 7.5 & 0.0475 & 0.0099 & 0.2218 & 0.0701 \\
\hline St11 & 27.0 & 35 & 8.2 & 7.8 & 0.0331 & 0.0070 & 0.2135 & 0.0419 \\
\hline St12 & 27.3 & 35 & 8.2 & 8.0 & 0.0268 & 0.0119 & 0.3117 & 0.0265 \\
\hline
\end{tabular}

Keterangan (Remark):

St : Lokasi pengamatan (Observation location)

Pengambilan sampel air pada kedalaman $4 \mathrm{~m}$ (Water sampling at water depth of $4 \mathrm{~m}$ ) 
Lampiran 5. Hasil analisis logam berat di perairan Teluk Kupang, Nusa Tenggara Timur Appendices 5. Results of heavy metal analysis in Kupang Bay, East Nusa Tenggara

\begin{tabular}{ccccc}
\hline $\begin{array}{c}\text { Kode Iokasi } \\
\text { Location } \\
\text { code }\end{array}$ & $\begin{array}{c}\text { Timbal (Pb) } \\
\text { Plumbum (Pb) } \\
\text { (mg/L) }\end{array}$ & $\begin{array}{c}\text { Kadmium (Cd) } \\
\text { Cadmium (Cd) } \\
\text { (mg/L) }\end{array}$ & $\begin{array}{c}\text { Seng (Zn) } \\
\text { Zinc (Zn) } \\
\text { (mg/L) }\end{array}$ & $\begin{array}{c}\text { Tembaga (Cu) } \\
\text { Cuprum (Cu) } \\
\text { (mg/L) }\end{array}$ \\
\hline St1 & 0.0049 & 0.0048 & 0.0005 & 0.0006 \\
St2 & 0.0044 & 0.0048 & 0.0007 & 0.0006 \\
St3 & 0.0044 & 0.0044 & 0.0007 & 0.0006 \\
St4 & 0.004 & 0.0046 & 0.0005 & 0.0006 \\
St5 & 0.0051 & 0.0048 & 0.0004 & 0.0007 \\
St6 & 0.0049 & 0.0044 & 0.0005 & 0.0007 \\
St7 & 0.0051 & 0.004 & 0.0007 & 0.0007 \\
St8 & 0.0042 & 0.004 & 0.0005 & 0.0007 \\
St9 & 0.0057 & 0.004 & 0.0008 & 0.001 \\
St10 & 0.0051 & 0.004 & 0.0005 & 0.0008 \\
St11 & 0.0053 & 0.0042 & 0.0004 & 0.0024 \\
St12 & 0.0057 & 0.0042 & 0.0004 & 0.0006 \\
\hline
\end{tabular}


